Debreceni Jogi Múhely 2015. (XII.) 3-4.

Debreceni Egyetem, Állam- és Jogtudományi Kar, Debrecen

(University of Debrecen, Faculty of Law, Debrecen)

DOI 10.24169/DJM/2015/3-4/7

\title{
Szmodis Jenő
}

egyetemi adjunktus

ELTE, Jog- és Társadalomelméleti Tanszék

\section{Az alkotmánybíráskodás elméleti alapjairól}

Debreceni Jogi Műhely, 2015. évi (XII. évfolyam) 3-4. szám (2015. december)

DOI $\underline{10.24169 / \mathrm{DJM} / 2015 / 3-4 / 7}$

I. Normakontroll vagy társadalmi kontroll

Az alkotmánybíráskodás intézménye, amely a modern korban az amerikai legfelsőbb bírósági gyakorlatból veszi eredetét, elméleti igényú, teoretikus megalapozását a normativista jogfilozófiában nyerte el.[1] Ebben a felfogásban az alkotmánybíróság tevékenysége alapvetően a formális normákhoz kapcsolódik, normáknak magasabb szintű normákkal való összemérésében manifesztálódik. Ez a felfogás azonban csalóka képet nyújt az alkotmánybíráskodásról, és elfedi az alkotmánybírósági tevékenység számos elemét. Az alkotmánybíróságok ugyanis éppúgy, mint az amerikai Legfelsőbb Bíróság, az alkotmánynak gyakran olyan értelmezését adják, amelyek messze túlmutatnak nem csupán az alkotmány szövegén, de a jogalkotó egykori szándékain is. Mindezt lehet ugyan ún. aktivista alkotmánybíráskodásként értelmezni, azt sugallva, hogy az ilyen gyakorlat legitim módja az egyébként sokféle utat és módot lehetővé tevő alkotmánybíráskodásnak,[2] azonban mindenképpen szembesülünk a kérdéssel, hogy hol húzódnak az alkotmánybíráskodás határai.

Az egyik legnagyobb problémát az jelenti, hogy az alkotmánybíráskodás normativista felfogása éppúgy félrevezető, mint maga a normativista jogelmélet. A fő probléma mindkét esetben az, hogy a jogbiztonság illúzióját nyúitja az a körülmény, hogy normáknak neveztetnek merôben nem pusztán normatív, sokkal inkább szociológiai, etikai mozzanatok. Amit például Kelsen hipotetikus alapnormának nevez, az éppen azáltal nem norma, hogy hipotetikus. Egy normativista jogfilozófia ugyanis nem mondhatott le arról, hogy mindent a normák nyelvén, a normák terminológiája szerint mondjon el és magyarázzon.

Amiként a tiszta jogtan sem megválaszolta a jog és az erkölcs viszonyának kérdését, hanem sokkal inkább elodázta a választ, ugyanígy az alkotmánybíráskodás normativista felfogása is szemérmesen elkendőzi a normában rejlő különböző értelmezési lehetőségeket, különböző erkölcsi állásfoglalások lehetőségét. A biztonság, a jogbiztonság illúziójának fenntartása érdekében figyelmen kívül hagyja Montaigne több mint négyszáz éves figyelmeztetését, nevezetesen, hogy ,ugyanannyi a szabadság és mozgás lehetősége a törvények értelmezésében, mint megalkotásukban.”[3]

Ha azonban ez igaz, akkor igencsak körültekintően kell megállapítani azokat a jogi lehetôségeket, amelyek az értelmezés számára rendelkezésre állnak. És - éppen Montaigne igazságából következően - még ekkor is számos probléma adódhat, hiszen a szabad értelmezésnek korlátokat szabni hivatott szabályok is meglehetősen szabadon értelmezhetőek. Ez utóbbi nehézség sem arról győzz meg, hogy a hátárok kijelöléséről le kell mondanunk, hiszen a határok mind pontosabb megvonása, ha nem is teszi ténylegesen lehetetlenné a határok megsértését, mindazonáltal nyilvánvalóbbá teszi azt. 
Debreceni Jogi Múhely 2015. (XII.) 3-4.

Debreceni Egyetem, Állam- és Jogtudományi Kar, Debrecen

(University of Debrecen, Faculty of Law, Debrecen)

DOI 10.24169/DJM/2015/3-4/7

\section{Eszmetörténet előzmények}

Az alkotmánybíráskodás legitimációs kérdéseinek, elvi alapjainak tisztázása szempontjából érdemes röviden áttekintenünk azokat a jogtörténeti és elméleti előzményeket, amelyek már jóval azt megelőzően felvetették a normakontroll problematikáját, hogy az alkotmánybíráskodás szervezeti modelljei kiépültek volna.

A „lex superior derogat legi inferiori” elve nem csupán a jogalkalmazás szempontjából kitüntetett jelentőségú, de a modern jogállam és az alkotmánybíráskodás kialakulása vonatkozásában is felbecsülhetetlen fontosságú. Nem utolsó sorban vezérelvévé vált a később kifejlődő jogpozitivizmusnak is, termékenyítő hatást gyakorolva a Merkl-Kelsen-féle joglépcső elméletre. A különböző normák sajátos, hierarchikus rendszerben való elképzelése azonban távolról sem modern jelenség, noha az ennek megfelelő, fokozottan árnyalt elméleti konstrukciók és intézményrendszerek kétségtelenül a XX. század termékei.

Az ókori Görögországban, noha a jogra külön kifejezést nem használtak,[4] a themisz fogalma sajátos egységét képezte a politikai-jogi, erkölcsi és vallási elgondolásoknak,[5] és a latin ius fogalmához legközelebb eső diké szó több értelmet is hordozott, Athénban mégis differenciált rendszere alakult ki a jogforrásoknak. Sokáig a szokásjog a legmeghatározóbb[6], amelynek idővel írásba foglalására is sor került (thezmosz).[7] A nómoszok (nómoi) mai fogalmaink szerint a törvényeknek feleltethetők meg, és kiemelt jelentőséget biztosított számukra szabályozási tárgyuk súlya és meghozataluk, illetve megváltoztatásuk különleges eljáráshoz kötöttsége.[8] A törvényjavaslatot a tanács (bule) terjeszthette a népgyúlés (eklészia) elé, de csak azt követően, hogy a hatezer tagú népbíróság (héliaia) hatszáz tagú különbírósága a javaslatról véleményt mondott. Ha a tervezet a különbíróság véleménye szerint az állam érdekét nem sértette, a javaslat a népgyűlés elé került. Ha az eklészia azt elfogadta, a törvény végső megszövegezését a különbíróság végezte el. A pszéfiszma népgyúlési határozat volt, és általában egyedi ügyekre vonatkozott, bár mind szélesebb körben tartalmazott általános magatartási szabályokat.[9] Bár Athénban normakontroll jogával felruházott külön szerv nem múködött, azonban a bírák a pszéfiszmákat akkor tették döntéseik alapjává, ha azok nem ellenkeztek a nómoszokkal.[10] Az antik Rómában az ősi jog formalitásainak oldódása után - mint említettük - sokáig a görög filozófián pallérozott jogtudósok véleményének volt kitüntetett jelentősége, sőt voltaképp legmagasabb jogforrási értéke.

A nyugati jogfejlődés későközépkori-kora újkori szakaszában a jogforrási hierarchia kérdése nem volt hangsúlyos probléma. Az abszolutizmus idôszakában az uralkodó által kiadott rendelkezéseknek feltétlen tekintélyük volt, és az uralkodói jogalkotás fokozatosan szorította ki a helyi szokásjogokat, elősegítve ezzel az országonként egységes jogrendszerek kialakulását. A polgári forradalmakat közvetlenül megelőzően, illetve e forradalmak nyomán helyeződött át a jogalkotás súlypontja előbb a rendi, majd a népképviseleti gyűlésekre, amelyeknek tevékenysége előbb háttérbe szorította, majd meg is szüntette az uralkodói jogalkotást.

A premodern társadalmakban, noha a jogrendszer nem volt homogén, azonban a szabályozást sokkal inkább egy sajátos mellérendeltség jellemezte, mintsem a mai fogalmaink szerinti formális jogszabályi hierarchia. Különös módon a jogszabályok hierarchiájának elve - illetve annak elóképe - abban az Angliában kezd körvonalazódni, ahol a formális jogalkotás útján keletkező statute law éppenséggel nem élvezett különös tekintélyt a common law-hoz képest. Mégis, az Angliában múködő nagyszámú társaságok és azok jelentősége szükségessé tette egy olyan elv megfogalmazását, ami a lex superior elv közvetlen előzményének tekinthető. A dicsőséges Forradalmat követően hangsúlyos elvvé vált, hogy a testületek akár magánjellegúek, akár közjogiak azok - csak saját chartájuk szerint múködhetnek. Múködésük során 
Debreceni Jogi Múhely 2015. (XII.) 3-4.

Debreceni Egyetem, Állam- és Jogtudományi Kar, Debrecen

(University of Debrecen, Faculty of Law, Debrecen)

DOI 10.24169/DJM/2015/3-4/7

nem terjeszkedhetnek túl tehát azon a felhatalmazáson, amelyet chartájuk számukra megállapít. Minden olyan testületi aktus semmis és bírósági úton nem kikényszeríthetô, ami a chartában foglaltakon túlterjeszkedik.

Tekintettel azonban arra, hogy a gyarmatok is királyi charták alapján múködtek - amelyek kizárták, hogy a gyarmati jogalkotás ellenkezzék az ésszerűséggel és a királyság törvényeivel - a Privy Council többször nyilvánította semmisnek a gyarmati törvényeket. A függetlenség 1776-os kinyilvánítása után az államokká alakuló korábbi gyarmatok a chartákat alkotmányokkal helyettesítették. A bírák azonban ezt követően a charták helyébe lépő új alkotmányokkal ellentétes törvényeket nyilvánították törvényteleneknek.[11] John Marshallnak a Marbury v. Madison ügyben 1803-ban hozott döntése elvi erôvel fejezte ki aztán, hogy „az alkotmánynak ellentmondó törvény semmis, és ez a bíróságokat, valamint a többi hatalmi ágat kötelezi."'[12]

A John Marshall által megfogalmazott elv idővel általánosabb értelmet nyert, és vonatkozott immár a törvények és az azoknak ellentmondó rendeletek, illetve a nemzetközi jog és az azzal ellentmondó belső jog viszonyára is. Megjegyzendő azonban, hogy a belső jog és a nemzetközi jog ütközésének problematikája kiváltképpen az I. világháborút követően vált hangsúlyossá.[13] Az amerikai Legfelsőbb Bíróság kebelében múködő alkotmánybíráskodáshoz képest sajátos utat jelentett a normakontroll európai, kontinentális kialakulása. Itt Kelsen kezdeményezésére önálló testületekként jöttek létre az alkotmánybíróságok. Bár az alkotmánybíróság létrehozását célzó osztrák előkészületek úttörő jellegúek voltak, mégis Csehszlovákiában jött létre elsőként ilyen testület az 1920. február 29-ei alkotmánnyal. Ezt követően a második Ausztriában az 1920. október 1-jei alkotmánnyal, majd bő tíz évre rá, 1931-ben pedig a köztársasági Spanyolországban. Utóbbit a Franco-rendszer szüntette meg, míg az előbbi kettő - tehát a csehszlovák, illetve az osztrák alkotmánybíróság utóda, a Szövetségi Bíróság (mely 1934-től egyesítette a Legfelsőbb Bíróság és az Alkotmánybíróság hatásköreit) - a terjeszkedô náci Németországnak esett áldozatul.[14]

Hogy a németek által megszállt területeken az alkotmánybíróságok megszüntetésére nem mintegy mellékesen, hanem nagyon is célzottan került sor, jól megvilágítja Hitlernek egy 1941-ből való megjegyzése, amit a jogászokra vonatkozóan tett. Ez egyúttal tükrözheti a húszas, harmincas években vélhetôen már körvonalazott álláspontját. A megjegyzés pedig nem csupán a Kelsen-féle, de mindenfajta így a nácikkal több, mint rokonszenvező[15], alapvetően konzervatív Carl Schmitt-féle jogászi megfontolásokra egyaránt vonatkozik. „Megteszek mindent, ami csak tölem telik, hogy megnehezitsem a jogászok életét, hogy lehetóleg minél kevesebben tanuljanak jogot. Annyira kompromittálni kell ę̧t a foglalkozást, hogy csak obyanok válasszák, akik nem törekednek másra, mint paragrafusok megismerésére. Mire valók a jogászi kifogások, amikor valamire néppolitikai okból szülkség van?”[16]Az odavetett mondatokból kiderül az is, hogy náci értelmezésben maguknak a „paragrafusoknak”, tehát nem a Rechtsstaat ideálja szerinti, a jogelveket is magában foglaló jognak, hanem a Führer-Prinzip által meghatározott tételes jognak lehet csupán szerepe. A jogelveket ebben a felfogásban valójában a Volkspolitik és a Führer-Prinzip helyettesíti. Nem sokban különbözik e nézet az állam és a jog elhalásáról szóló kommunista elképzelésektől, ahol átmenetileg még létező pozitív jogon túl az osztályakarat tekintendő meghatározónak.

III. Az alkotmánybíráskodás felvirágzása és vadvirágai

A második világháborút követően Nyugat-Európa számos demokráciááaban jöttek létre alkotmánybíróságok, míg erre Közép-Európában a kommunista rendszerek bukásával összefüggésben 1989-1990-től kezdődően került sor. Vitathatatlan elvvé vált a lex superior derogat legi inferiori elve és még számos jogelv, amelyek bővebb kifejtésében és érvényre juttatásában éppen az alkotmánybíróságok is nagy szerepet játszottak. Kialakulni látszott, illetve látszik azonban egy olyan tendencia is, hogy a jogelvek közül 
Debreceni Jogi Múhely 2015. (XII.) 3-4.

Debreceni Egyetem, Állam- és Jogtudományi Kar, Debrecen

(University of Debrecen, Faculty of Law, Debrecen)

DOI 10.24169/DJM/2015/3-4/7

inkább azok részesülnek előnyben, amelyeket a pozitív jog szabályai közé felvesz. Ilyenkor ráadásul az elvek hatókörét a joggyakorlat igyekszik annak a jogszabálynak a hatálya alatt tartani, amelyik jogszabály az adott elvet tartalmazza. Így Magyarországon például a visszaható hatály tilalmának, valamint a nullum crimen sine lege elvét igyekezett - némileg erőltetett módon - érvényesíteni az Alkotmánybíróság a szocializmus bűneinek megbüntetését célzó, az elévülés nyugvását rögzíteni kívánó törekvések ellenében. Ezzel szemben fel sem merült $a$,senki a maga felróbató magatartására nem bivatkoz̧hat” polgári jogias eredetü elve, noha a bűnösök a rendszer fenntartásában való közremúködésükkel maguk idézték elő, hogy a büntethetôségük felelősségre vonás nélkül évült el.

Meg kell jegyezni azonban azt is, hogy a magyar Alkotmánybíróság múködésének első, kritikus évtizede után egyre inkább világossá tette, hogy az alapvető fontosságú jogelvek érvényesülésének nincsenek jogági határai. Az Alkotmánybíróság ugyanis az 1990-es évek végén, az ún. igazságtétel ügyéhez képest lényegesen kisebb súlyú ügyben a 31/1998 (VI.25.) AB számú döntésében rámutatott, hogy a joggal való visszaélés tilalma az egész jogrendszerben érvényesül, így függetlenül az ún. jogági struktúra határaitól. A 18/2008 (III.12.) AB határozat pedig az Alkotmánynak a jogállamiságra és a jogbiztonságra vonatkozó rendelkezése alapján következtetett arra, hogy a rendeltetésszerú joggyakorlás követelményének alkotmányos elv. Utóbbi határozatával, illetve annak indoklásával az Alkotmánybíróság egyúttal közelítette a jogállamiság és a jogbiz̨tonság elveit is, kevésbé konkuráló, mintsem egymást kiegészító-értelmező elvekként felfogva azokat. Utóbbi döntésekből azonban az is nyilvánvaló, hogy az 1990-es évek elején megkérdójelez̧hetöen járt el az Alkotmánybíróság, amikor egy büntetőjogi kérdésben figyelmen kívül hagyott egy olyan jogelvet, amely ugyan a civiljogból veszi eredetét, azonban általánosságához - a hivatkozott 1998-as és 2008-as határozatok tükrében - immár nem férhet kétség. Az igazságtételi-elévülési törvények esetén ugyanis figyelembe lehetett volna venni azt a körülményt, hogy az 1956 utáni megtorlásokban résztvevők a rendszer fenntartásában játszott közremúködésükkel elóidézték a büntethetőségük elévülését. Amennyiben az Alkotmánybíróság az alkotmányosság egyik legfontosabb intézménye[17], különösen indokolt lett volna az e szempontból releváns jogelv tekintetbe vétele is.

A „senki a maga felróható magatartására elönyök szerzésére nem bivatkoz̧at elve”éppenséggel a joggal való visszaélést és a rendeltetésellenes joggyakorlás lehetőségét zárja ki. $\mathrm{Ha}$ azonban utóbbi elvek a jogrendszer egészére irányadóak, úgy e minőséget aligha lehet megtagadni az ezeket az elveket pusztán konkrétabban kifejező jogelvtől sem.

Annak érdekében, hogy az alkotmánybíráskodás a jogfejlesztés legitim szerve legyen és maradjon, álláspontom szerint feltétlenül célszerú tisztázni, hogy egy alkotmánybíróságnak mi a szerepe a jogpolitika[18] alakításában. Az alkotmánybíróság vitathatatlanul rendelkezik szakpolitikával kapcsolatos funkciókkal. A jogalkotás legitimitásának szempontjából álláspontom szerint azonban alapvető fontosságú tétel, hogy a jogpolitika aktív alakításáért (az alkotmányos értékek összhangjának megteremtéséért, a főbb hangsúlyok kijelöléséért) a választott országgyúlés és kormány tartozik felelősséggel, így ő rendelkezik a jogpolitika alakításának legfőbb jogosítványaival is.

Nehéz kérdést vet fel annak meghatározása, hogy vajon egy alkotmánybírósági döntés mikor terjeszkedik túl a puszta normakontrollon, mikor válik a normakontroll rejtett értékválasztássá, jogpolitikai jellegú munkává. Az egzakt elhatárolás esetról esetre vizsgálandó, és a biztos itélet megalkotása még akkor is szinte lehetetlen. Megitélésem szerint azonban fontos szempont lehet a logikai-normativ határozatoknak a jogpolitikai jellegü határozatoktól való elhatárolásához annak vizsgálata, hogy az alkotmánybíróság azonos alkotmányos szabályok mellett az adott ügyben juthatott volna-e ellentétes álláspontra. 
Debreceni Jogi Múhely 2015. (XII.) 3-4.

Debreceni Egyetem, Állam- és Jogtudományi Kar, Debrecen

(University of Debrecen, Faculty of Law, Debrecen)

DOI 10.24169/DJM/2015/3-4/7

\section{Summary - On theoretical bases of Constitutional Court's activity}

The paper researches preliminarily the problem of norm-control versus social-control. It criticizes the logical and normative approach of Consctitutional Court's activity, pointing out this function necessarily deals with values. The paper introduces the ideological and historical antecedents of modern institutional norm-control, touching Grecian and early American ideas. The article finally refers spread of Constitutional Courts and some problematical phenomena of Hungarian Constitutional Court's activity.

[1] Az alkotmánybíróság intézményének a felállitásával kapcsolatos kezdeményezések története alighanem még további kutatásokat igényel. Nehezen megállapítható, hogy a kezdeményezésben kit illet az elsőség, annyi azonban valószínú, hogy a gondolat még az Osztrák-Magyar Monarchia utolsó évtizedeire nyúlnak vissza. A témában lásd bővebben Halmai Gábor: Hans Kelsen és a magyar Alkotmánybíróság. Világosság 2005/11. 3-14.

[2] Pokol Béla: A magyar parlamentarizmus. Cserépfalvi, Budapest, 1994. 94-110.

[3] Montaigne: A tapasztalásról. Európa Könyvkiadó. Budapest. 1983. 6.

[4] Stipta István: Az ókori görög állam- és jogfejlődés. In Horváth Pál - Révész T. Mihály (szerk.): Általános jogtörténet I. Nemzeti Tankönyvkiadó, Budapest, 1996. 33-41. 40.

[5] John Walter Jones. : The Law and the Legal Theory of the Greeks. Aalen. Scientia Verlag. 1956/1977. 32sk.

[6] Nagy Lászlóné: Az ókori görög állam- és jogfejlődés. In Horváth Pál (szerk.): Egyetemes állam- és jogtörténet. Tankönyvkiadó, Budapest, 1988. 38-54. 47.

[7] Stipta i.m. 40.

[8] Mauro Cappelletti - William Cohen: Az alkotmánybíráskodás története és jelenkori elterjedése. In Paczolay Péter (szerk.): Alkotmánybíráskodás, alkotmányértelmezés. Jogfilozófiák 1995. Budapest 42-52. 43-44. A mú eredeti címe és megjelenése: The history and contemporary expansion of judicial review; in Comparative Constitutional Law. Bobbs-Merill, Indianapolis, 1979. 3-16.

[9] Mauro Cappelletti - William Cohen i.m. 44.

[10] Mauro Cappelletti - William Cohen 44.

[11] Mauro Cappelletti - William Cohen: Az alkotmánybíráskodás története és jelenkori elterjedése. In Paczolay Péter (szerk.): Alkotmánybíráskodás, alkotmányértelmezés. Jogfilozófiák 1995. Budapest. 42-52. 48-49. A mú eredeti címe és megjelenése: The history and contemporary expansion of judicial review; in Comparative Constitutional Law. Bobbs-Merill, Indianapolis, 1979. 3-16.

[12] Lásd ugyanott 50.

[13] Klaus von Beyme: Alkotmánybíráskodás. In In Paczolay Péter (szerk.): Alkotmánybíráskodás, alkotmányértelmezés. Jogfilozófiák 1995. Budapest. 117-127. 118. A mú eredeti címe és megjelenése: Judicial review. In: America as a model. The impact of American democracy in the world. St. Martin's Press, New York, 1987. 85-109.

[14] Louis Favoreu: Az alkotmánybíróságok. In Paczolay Péter (szerk.): Alkotmánybíráskodás, alkotmányértelmezés. Jogfilozófiák 1995. Budapest. 53-116. 70. A mú eredeti címe és megjelenése: Les Cours Constitutionnelles. Paris. Presses Universitaires de France, 1992. (2. ed.) 1-105.

[15] Amint Karácsony András megjegyzi: „A konzervatív forradalom eszmevilágával érintkező Carl Schmitt volt az egyetlen, aki ebből a szellemi körből Hitler hatalomra jutását követően azonnal a nemzetiszocializmus híve lett. 1933-1936 között számos beszédben és cikkben fejezte ki feltétlen odaadását az új rezsim iránt, többek között az 1934-es A Führer oltalmazza a jogot címú írásában." Karácsony András: A konzervatív forradalom utópiája a két háború közötti Németországban. In Karácsony András: Mozaikok, Politika - Értelmiség - Konzervativizmus. Attraktor, Máriabesnyő, 2014. 
Debreceni Jogi Múhely 2015. (XII.) 3-4.

Debreceni Egyetem, Állam- és Jogtudományi Kar, Debrecen

(University of Debrecen, Faculty of Law, Debrecen)

DOI 10.24169/DJM/2015/3-4/7

220-254. 244. A hivatkozott 1934-es Schmitt-cikk magyarul is olvasható: Carl Schmitt: A Führer oltalmazza a jogot. In Carl Schmitt: A politika fogalma (ford. Cs. Kiss Lajos). Osiris - Pallas Stúdió Attraktor Kft., Budapest, 2002. 227-230.

[16] Adolf Hitler: Asztali beszélgetések. Monológok a vezérkari főhadiszálláson 1941-1944. Közreadta Werner Joachim. Ármádia Kiadó, Budapest, 1999. 133. (1941. november 16-ai monológ)

[17] Kukorelli István: Alkotmánytan. Osiris Kiadó, 2007. 441.

[18] Jogpolitika alatt itt nem a jogi értéktannak is nevetett tudományos tevékenységet értjük (Moór Gula: Tegnap és a holnap között. Révai, Budapest, 1947.166.; Moór Gyula: Jogfilozófia. Püski, Budapest, 1994. 17-21.), hanem a jog meghatározott értékválasztás alapján történő tényleges, aktív alakítását (Szabó Miklós: Jogpolitika. Kézirat. http://jogikar.uni-miskolc.hu/projectSetup/files/imj/kozpolitika-ba/szakkozpolitikak.pdf). 